Fixed Point Theory, 20(2019), No. 1, 177-184

DOI: $10.24193 /$ fpt-ro.2019.1.10

http://www.math.ubbcluj.ro/ nodeacj/sfptcj.html

\title{
A FIXED POINT THEOREM IN UNIFORM SPACES GENERATED BY A FAMILY OF b-PSEUDOMETRICS
}

\author{
HAMID FARAJI*, KOUROSH NOUROUZI** AND DONAL O'REGAN*** \\ *Department of Mathematics, Science and Research Branch \\ Islamic Azad University, Tehran, Iran \\ **Faculty of Mathematics, K. N.Toosi University of Technology \\ P.O. Box 16315-1618, Tehran, Iran \\ E-mail: nourouzi@kntu.ac.ir \\ *** School of Mathematics, Statistics and Applied Mathematics \\ National University of Ireland, Galway, University Road, Galway, Ireland
}

\begin{abstract}
In this paper, we discuss the existence of fixed points of mappings defined on uniform spaces generated by a family of $b$-pseudometrics. We also give some sufficient conditions under which the fixed point is unique.

Key Words and Phrases: Uniform spaces, b-pseudometrics, fixed points.
\end{abstract}

2010 Mathematics Subject Classification: $47 \mathrm{H} 10$.

\section{REFERENCES}

[1] S.P. Acharya, Some results on fixed points in uniform spaces, Yokohama Math. J., 22(1974), 105-116.

[2] V. Angelov, Fixed Points in Uniform Spaces and Applications, Cluj University Press, 2009.

[3] I.A. Bakhtin, The contraction mapping principle in almost metric space, Functional analysis, (Russian), Ulýanovsk. Gos. Ped. Inst., Ulýanovsk, (1989), 26-37.

[4] S. Czerwik, Contraction mappings in b-metric spaces, Acta Math. Inform. Univ. Ostraviensis, 1(1993), 5-11.

[5] S. Czerwik, Nonlinear set-valued contraction mappings in b-metric spaces, Atti Sem. Mat. Fis. Univ. Modena, 46(1998), 263-276.

[6] J. Heinonen, Lectures on Analysis on Metric Spaces, Universitext, Springer-Verlag, New York, 2001.

[7] K.D. Joshi, Introduction to General Topology, John Wiley Sons, Inc., 1983.

[8] M.A. Khamsi, N. Hussain, KKM mappings in metric type spaces, Nonlinear Anal., 73(2010), no. 9, 3123-3129.

[9] W. Kirk, N. Shahzad, Fixed Point Theory in Distance Spaces, Springer, Cham, 2014.

[10] A. Petruşel, G. Petruşel, B. Samet, J.-C. Yao, Coupled fixed point theorems for symmetric multi-valued contractions in b-metric space with applications to systems of integral inclusions, J. Nonlinear Convex Anal., 17(2016), no. 7, 1265-1282.

[11] A. Petruşel, G. Petrussel, B. Samet, J.-C. Yao, Coupled fixed point theorems for symmetric contractions in b-metric spaces with applications to operator equation systems, Fixed Point Theory, 17(2016), no. 2, 457-475. 
[12] W. Sintunavarat, Nonlinear integral equations with new admissibility types in b-metric spaces, J. Fixed Point Theory Appl., 18 (2016), no. 2, 397-416.

[13] S. Willard, General Topology, Addison-Wesley Publishing Co., Reading, Mass.-London-Don Mills, Ont., 1970.

Received: September 6, 2016; Accepted: November 11, 2016. 
